\title{
France wins larger share of patent royalties after AIDS test dispute
}

Washington. The Pasteur Institute in France has won a three-year battle with the US National Institutes of Health (NIH) for a larger share of patent royalties from AIDS tests developed jointly by scientists at the two institutions.

Under a deal agreed on Monday by the French and American AIDS Foundation (FAAF) - the body established in 1987 to distribute the royalties - the NIH formally acknowledged that the test kit that it developed made use of a virus provided by the Pasteur Institute.

In future, FAAF will distribute the patent royalties according to a new formula that will give the Pasteur Institute more money than the NIH. But Harold Varmus, director of NIH, says that the new deal is consistent with the intention of the original 1987 agreement, as it gives both countries equal shares of the royalties over the full life of the patent.

Up to now, the United States has been receiving a larger share of royalties than
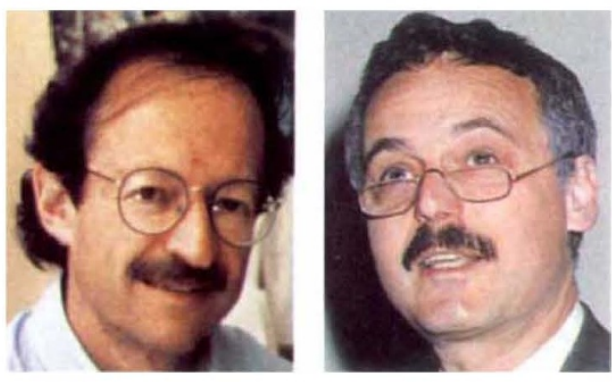

Burying the hatchet: Varmus of NIH (left) and Schwartz of the Pasteur Institute.

France - so far it has received \$20 million and France \$14 million - as the US AIDS test kit has had far larger sales than the French one.

The United States is seeking to characterize the new deal as an adjustment needed to address this apparent anomaly. But the French are presenting it as a victory on an important matter of principle. Either way, the resultant compromise should at least

\section{Bomb builders 'motivated by fear'}

Moscow. Russian scientists have claimed that the Soviet physicists involved in building an atomic bomb in the late 1940 s were motivated by the fear that, if they failed, they would be dismissed as 'idealists' and suffer the same fate as biologists had done under Joseph Stalin.

In an open letter, the scientists admit that the construction of the first bomb, which was successfully tested in 1949 , was made possible only because secrets were transferred from the West (in contrast to two further atomic weapons tested in 1951 - as well as the later hydrogen bombs - that were products of Russian science).

They also criticize recent claims made in the book Special Tasks, written by the former Soviet spy, Pavel Sudoplatov, that the physicist Robert Oppenheimer was involved in passing nuclear secrets to the Russians. (Last week, the son of Lavrenti Berio, who was responsible for the security surrounding the Russian bomb project, added further speculation to this story by claiming that Oppenheimer had stayed at his father's house in 1939.)

The signatories to the letter, headed by Vitaly Goldansky, until recently the head of the Chemico-Physical Institute of the Russian Academy of Sciences, express particular concern that history is being "rewritten" in a way that presents their immediate predecessors as "mere imitators" of work carried out elsewhere, based on blueprints obtained by Soviet spies operating in the West.

Voicing their support for a leading article in Nature $(368,779 ; 1994)$ which condemned the inferences in the book that not only Oppenheimer but also Niels Bohr, Enrico Fermi and Leo Szilard were involved in passing nuclear secrets to Russia, they warn of a growing tendency to make science a scapegoat for Russia's current difficulties.

But, in what is perhaps the most intriguing suggestion, they argue that physicists in the 1940 s faced the prospect that those who expressed belief in the theory of relativity would be condemned as 'idealists' - and would therefore suffer the same fate as those who opposed the ideas of 'man-directed' evolution propagated by Stalin's protégé, Trofim Lysenko.

The successful demonstration of nuclear weapons apparently put an end to this threat, and physicists subsequently came to occupy positions of power and prestige in the post-war Soviet Union. Signatories to the open letter in addition to Goldansky include Valery Subbotin, Alexander Chudakov, Alexander Fokin, Mikhail Styrikovich, Yuri Osipian, Zhores Alferov, Alexander Skrinsky, and Alexander Andreev. Carl Levitin restore working relations between Pasteur and NIH.

Under the 1987 agreement, both countries keep 20 per cent of their kit royalties, and pool the remaining 80 per cent. The old agreement gave one quarter of the pooled money to the World AIDS Foundation (WAF), which funds AIDS research and education in developing countries, and divided the rest equally between the US and France. The new deal gives France half of the total, and the United States and the WAF one quarter each.

According to both parties, the deal resolves the argument between Pasteur and $\mathrm{NIH}$ on the matter for good. But it will not resolve the question of whether the NIH research team, led by Robert Gallo, misappropriated the French virus accidentally or deliberately.

Gallo attended the FAAF meeting and endorsed the deal. In a statement issued through his lawyer after the meeting, he claimed that the deal "simply implements the spirit of the 1987 settlement".

Pasteur had originally sought an agreement that would have given it three-quarters of the pooled money, the WAF a quarter, and the NIH nothing. But director-general Maxime Schwartz says that his earlier stance was merely a negotiating position, and that he is satisfied with the final outcome.

"I'm very pleased that a decision was taken to change the distribution of royalties in a way that is much more fair than it was before," Schwartz said after the meeting, adding that the formal acknowledgement from the US side that the US test was based on the French virus was more important to Pasteur than the financial settlement.

Asked why he had changed his mind between 8 June, when he rejected Schwartz's pleas for a renegotiation of the deal, and 23 June, when he offered talks (see Nature 369 $693 ; 1994)$, Varmus said that conversations with Schwartz during this period had made him see the dispute "in a slightly different context".

Varmus said the appearance of a report prepared by the inspector general of the health department on 10 June had "very little" impact on his change of mind. He says that the decision to negotiate was his alone, and denies that it had been influenced by pressure from the chairman of the House energy and commerce committee John Dingell (Democrat, Michigan), whose staff have kept a keen interest in the Gallo case. Varmus adds that he sees no need for the Office of Research Integrity, which last year dropped a case against Gallo, to revisit the matter.

Colin Macilwain 